Писаренко П. В., доктор сільськогосподарських наук

Полтавська державна аграрна академія

Москалець В. В., кандидат сільськогосподарських наук

Білоцерківський національний аграрний університет

\title{
АГРОЕКОЛОГІЧНІ ОСОБЛИВОСТІ ВПЛИВУ МІКРОБНИХ ПРЕПАРАТІВ НА КІЛЬКІСНІ ПАРАМЕТРИ ЯКОСТІ ЗЕРНА ТРИТИКАЛЕ ОЗИМОГО
}

\author{
Рецензент - доктор сільськогосподарських наук В. В. Лавров
}

\begin{abstract}
Досліджено чутливість генотипів тритикале озимого на дію мікробних препаратів альбобактерину і діазобактерину за показниками якості зерна, в результаті чого сортовий набір цієї культури, який входив до дослідів, був диференційований за рівнем чутливості на дію біоатентів конкретного препарату на: чутливі (на діазобактерин: «АД 256», "Славетне»; на альбобактерин: «Вівате Носівський», «Ягуар», «Августо», «Славетне»); помірно чутливі (на діазобактерин: «Августо») та нечутливі (на діазобактерин: «Вівате Носівський», «Ягуар», «ДАУ 5»; на альбобактерин: «АД 256», «ДАУ 5»). Доведено здатність тритикале озимого сортів «АД 256», «Славетне» та «Вівате Носівський» під впливом мікробних препаратів забезпечувати на чорноземі типовому малогумусному легкосуглинковому иентрального Лісостепу Украӥни високу якість зерна.
\end{abstract}

Ключові слова: тритикале озиме, сорт, мікробні препарати, кількісні параметри якості зерна.

Постановка проблеми. Якісні параметри рослинницької продукції визначаються низкою агроекологічних факторів. По-перше, кількісні параметри якості продукції залежать від грунтових і кліматичних особливостей агроекосистеми; по-друге, - від виду тієї чи іншої агротехнології вирощування та строків і своєчасності виконання складових певних операційних систем; потретє, - від сорту, лінії чи гібриду, за умов їх своєчасного оновлення тощо. Забезпечити високу урожайність сільськогосподарських культур за якісними показниками шляхом поєднання найважливіших факторів, що їх зумовлюють, досить складно: в динаміці (у сівозміні) ці показники будуть істотно різнитися. Проте тенденція, зазвичай, зберігатиметься, порівняно з варіантами, на яких аналогічних агротехнологій не застосовано або недотримана своєчасність їх виконання. Впровадження до традиційних агротехнологій вирощування сільськогосподарських культур шляхом додавання елементів біологізації дає можливість розв'язати питання 3 поліпшення якості рослинницької продукції, проте непередбачувані фактори (погодно-кліматичні аномалії, агротехнічні огріхи) можуть призводити до відсутності бажаних результатів.

Аналіз основних досліджень і публікацій, у яких започатковано розв'язання проблеми. Найважливіша особливість екологічного землеробства полягає в активізації природних азотфіксуючих систем, завдяки яким забезпечується живлення сільськогосподарських культур переважно за рахунок біологічного азоту та фосфору $[1,9]$. Досвід і практика показали, що для одержання максимальної кількості продукції 31 га землі необхідно не тільки збільшити постачання азотних і фосфорних добрив, але й інтенсифікувати біологічне нагромадження азоту та фосфору $[7,8]$. Ліквідація азотного дефіциту, що формується в результаті виносу цього елемента 3 грунту рослинами, вимивання, денітрифікації, проходить лише за рахунок впливу мінеральних добрив [11]. Важливе значення для поліпшення якісних параметрів урожаю рослинницької продукції та грунту має низка агротехнологій, які передбачають застосування мікробних препаратів, на основі активних штамів азотфіксуючих i фосфатмобілізуючих мікроорганізмів [2, 7]. Внесення мікробних препаратів у агрофітоценози тритикале озимого є малодослідженим аспектом, тому подальші дослідження є актуальними.

Мета досліджень - дослідити стан агрофітоценозу тритикале озимого за показниками якості зерна за прогресивних елементів агротехнології вирощування в умовах центрального Лісостепу.

Матеріали і методи досліджень. Польові та лабораторні дослідження проводили згідно 3 загальноприйнятими методами [3, 6]. Дослідження агротехнології вирощування проведено впродовж 2008-2011 років на стаціонарі навчальнонаукового дослідного центру Білоцерківського національного аграрного університету (ННДЦ БНАУ), що в Київській області. Схема дослідів 
включала 8 варіантів: 1-й - контроль; 2-й - Діазобактерин; 3-й - Альбобактерин; 4-й - Діазобактерин + Альбобактерин; 5-й - $\mathrm{N}_{45} \mathrm{P}_{45} \mathrm{~K}_{45} ; 6$-й $\mathrm{N}_{45} \mathrm{P}_{45} \mathrm{~K}_{45}+$ Діазобактерин; 7-й $-\mathrm{N}_{45} \mathrm{P}_{45} \mathrm{~K}_{45}+$ Альбобактерин; 8-й $-\mathrm{N}_{45} \mathrm{P}_{45} \mathrm{~K}_{45}+$ Діазобактерин + Альбобактерин.

Грунт дослідних ділянок - чорнозем типовий малогумусний легкосуглинковий на карбонатному лесі. Площа варіанту досліду складала $35 \mathrm{~m}^{2}$, облікова $-30 \mathrm{~m}^{2}$.

Залежно від умов закладання досліду, попередниками для тритикале озимого були вико-вівсяна суміш, конюшина на зелену масу.

Застосовували загальноприйняту для Лісостепу та Полісся технологію вирощування цієї культури.

Назва сортів тритикале озимого, які були залучені до дослідів: «АД 256», «Славетне», «Вівате Носівський», «Ягуар», «Августо», «ДАУ 5».

Фенологічні спостереження проводили за методикою [10]. Морфологічні дослідження виконували за методикою I. Г. Серебрякова [10] та $Ф$. М. Куперман [4], аналіз структури урожаю за методикою Н. О. Майсуряна [5].

Кількісні параметри якісного складу зерна визначали методом корелятивної інфрачервоної спектроскопії у ближній ІЧ-області спектра за допомогою аналізатора NIR-4500.

Математично-статистичну обробку даних здійснювали за О. Б. Доспєховим [3] та з використанням комп'ютерних програм Statistica-5.5 та Excel-2003.

Результати досліджень. За результатами аналізу даних із визначення якості зерна з'ясовано, що конкретний сорт тритикале озимого порізному реагує на дію конкретного біопрепарату за однакових агрокліматичних, грунтових і агротехнічних умов. Це, в свою чергу, дало змогу диференціювати сортовий склад цієї культури за рівнем чутливості на дію інтродукованих, шляхом передпосівної інокуляції, мікроорганізмів.

Отже, за результатами досліджень сортовий набір тритикале озимого був структурований на: чутливі, помірно-чутливі та нечутливі залежно від дії певного біопрепарату на конкретний сорт (табл. 1).

Посіви сорту «АД 256» під впливом препарату азотфіксуючих мікроорганізмів Azospirillum brasilense діазобактерину забезпечують збільшення вмісту білку в зерні на 11,3 і 5,2 \%, порівняно з вмістом його в зерні на варіантах без застосування мікробних препаратів і застосування препарату фосфатмобілізуючих бактерій Achromobacter album 1122 - альбобактерину (табл. 2).

Застосування альбобактерину на фоні $\mathrm{N}_{45} \mathrm{P}_{45} \mathrm{~K}_{45}$ зумовлює зростання крохмалю в зерні на $1,5 \%$ порівняно 3 варіантом застосування лише мінеральних добрив.

\section{1. Диференціація сортів тритикале озимого за рівнем чутливості на дію мікробних препаратів, діючими агентами яких с активні штами азотфіксуючих та фосфатмобілізуючих мікроорганізмів, ННДЦ БНАУ, середнє за 2008-2011 рр.}

\begin{tabular}{|c|c|c|c|}
\hline \multirow{2}{*}{$\begin{array}{c}\text { Назва мікробного } \\
\text { препарату }\end{array}$} & \multicolumn{3}{|c|}{ Рівень чутливості } \\
\hline & чутливий & помірно чутливий & нечутливий \\
\hline Діазобактерин & «АД 256», «Славетне» & «Августо» & $\begin{array}{c}\text { «Вівате Носівський», } \\
\text { «Ягуар», «ДАУ 5» }\end{array}$ \\
\hline Альбобактерин & $\begin{array}{l}\text { «Вівате Носівський», } \\
\text { «Ягуар», «Августо» }\end{array}$ & - & «АД 256», «ДАУ 5» \\
\hline $\begin{array}{l}\text { Діазобактерин + } \\
\text { Альбобактерин }\end{array}$ & «Славетне» & - & $\begin{array}{c}\text { «ДАУ } 5 », \text { «Августо», } \\
\text { «Ягуар», «Вівате Носівський» }\end{array}$ \\
\hline
\end{tabular}

\section{2. Вилив мікробних препаратів на кількісні характеристики якості зерна тритикале} озимого «АД 256», ННДЦ БНАУ, середнє за 2008-2011 рр.

\begin{tabular}{|c|c|c|}
\hline Назва варіанта & Вміст білка, $\%$ & Вміст крохмалю, \% \\
\hline Контроль & $11,5 \pm 0,01$ & $69,6 \pm 0,24$ \\
\hline Діазобактерин & $12,8 \pm 0,02$ & $70,1 \pm 0,39$ \\
\hline Альбобактерин & $12,1 \pm 0,01$ & $70,0 \pm 0,41$ \\
\hline $\mathrm{N}_{45} \mathrm{P}_{45} \mathrm{~K}_{45}$ & $12,4 \pm 0,03$ & $70,3 \pm 0,16$ \\
\hline Діазобактеритерин & $13,2 \pm 0,07$ & $71,5 \pm 0,14$ \\
\hline $\mathrm{N}_{45} \mathrm{P}_{45} \mathrm{~K}_{45}+$ Діазобактерин & $12,6 \pm 0,11$ & $70,9 \pm 0,32$ \\
\hline $\mathrm{N}_{45} \mathrm{P}_{45} \mathrm{~K}_{45}+$ Альбобактерин & $13,0 \pm 0,05$ & $72,6 \pm 0,07$ \\
\hline $\mathrm{N}_{45} \mathrm{P}_{45} \mathrm{~K}_{45}+$ Діазобактерин + Альбобактерин & $12,7 \pm 0,12$ & $72,0 \pm 0,54$ \\
\hline
\end{tabular}


Аналіз даних щодо якісних параметрів зерна тритикале озимого сорту «Славетне» на варіантах із застосуванням мікробних препаратів (діазобактерину та альбобактерину) показав, що вміст крохмалю та білку збільшується пропорційно їх застосуванню, порівняно з контролем. Синергетична взаємодія азотфіксуючих і фосфатмобілізуючих мікроорганізмів біопрепаратів в агрофітоценозі цього сорту зумовлює збільшення порівняно з контролем показників вмісту білка у зерні - на $11,7 \%$, крохмалю - на 5,8\%, (табл. 3). 3'ясовано, що посіви тритикале озимого сорту «Вівате Носівський», «Августо» та «Ягуар» суттєво реагували на дію лише мікробного препарату фосфатмобілізуючих мікроорганізмів альбобактерину. У разі проведення аналізу даних щодо якості зерна було показано, що під впливом альбобактерину істотно (p > 0,05) збільшується вміст крохмалю та фосфору, при цьому вміст білкова в зерні залишається сталим незалежно від варіанту досліду (табл. 4). Застосування альбобактерину на посівах сорту «Вівате Носівський» зумовлювало істотне $(\mathrm{p}>0,05)$ зростання вмісту крохмалю та фосфору в зерні: на 4,7 і 25,2 та 3,5 і 19,0 \% відповідно, порівняно 3 контролем і варіантом із застосуванням діазобактерину.

Аналіз даних щодо порівняння сортів за якісними параметрами урожаю зерна за умов дії конкретного мікробного препарату показав, що сорти тритикале озимого «Вівате Носівський», «Ягуар» і «Августо» істотно різняться у разі застосування фосфатмобілізуючих мікроорганізмів альбобактерину (рис. 1).

3 рисунка 1 видно, що сорти тритикале озимого диференціюються за показником вмісту білка у зерні, найвищий вміст якого забезпечує альбобактерин у сорті Вівате Носівський, порівняно з Ягуаром та Августо. Проте найвищі показники вмісту крохмалю в зерні забезпечує сорт Августо.

Посіви сортів тритикале озимого АД 256 i Славетне за показниками якості зерна - вмісту білка та крохмалю, істотно реагують на дію діазобактерину. Проте сорт Славетне нагромаджує більше білка і крохмалю за умов комплексного застосування діазобактерину та альбобактерину, порівняно з показниками, отриманими на варіантах моноінокуляції біопрепаратами (рис. 2).

Механізм дії кожного з біопрепаратів зрозумілий. Азотфіксуючі бактерії діазобактерину Azospirillum brasilense забезпечують рослини тритикале біологічним азотом за рахунок функціонування ферменту нітрогенази, а бактерії альбобактерину Achromobacter album 1122 - біологічним фосфором. Ефективність комплексу діазобактерину та альбобактерину на посівах сорту «Славетне» можна обгрунтувати тезою провідних вчених у галузі мікробіології: процес біологічної азотфіксації потребує значних витрат енергії й тому часто лімітується нестачею фосфору, який входить до складу аденозинтрифосфорної кислоти (АТФ) [2, 7].

Таким чином, конкретний сорт по-різному чутливий на дію певних мікробних препаратів за кількісними та якісними показниками урожаю.

3. Вилив мікробних препаратів на кількісні характеристики якості зерна тритикале озимого "Славетне», ННДЦ БНАУ, середнє за 2008-2011 рр.

\begin{tabular}{|c|c|c|}
\hline Назва варіанта & Вміст білка, $\%$ & $\begin{array}{c}\text { Вміст } \\
\text { крохмалю, } \%\end{array}$ \\
\hline Контроль & $12,8 \pm 0,05$ & $68,9 \pm 0,31$ \\
\hline Діазобактерин & $13,7 \pm 0,04$ & $70,5 \pm 0,12$ \\
\hline Альбобактерин & $13,4 \pm 0,02$ & $71,5 \pm 0,41$ \\
\hline $\mathrm{N}_{45} \mathrm{P}_{45} \mathrm{~K}_{45}$ & $14,3 \pm 0,03$ & $72,9 \pm 0,25$ \\
\hline Діазобактеринберин & $14,6 \pm 0,12$ & $72,6 \pm 0,32$ \\
\hline $\mathrm{N}_{45} \mathrm{P}_{45} \mathrm{~K}_{45}+$ Діазобактерин & $14,8 \pm 0,04$ & $71,7 \pm 0,53$ \\
\hline $\mathrm{N}_{45} \mathrm{P}_{45} \mathrm{~K}_{45}+$ Альбобактерин & $14,7 \pm 0,08$ & $72,8 \pm 0,07$ \\
\hline $\mathrm{N}_{45} \mathrm{P}_{45} \mathrm{~K}_{45}+$ Діазобактерин + Альбобактерин & $14,8 \pm 0,11$ & $73,5 \pm 0,18$ \\
\hline
\end{tabular}

4. Вилив мікробних препаратів на кількісні характеристики якості зерна тритикале озимого Вівате Носівський, ННДЦ БНАУ, середнє за 2008-2011 рр.

\begin{tabular}{|c|c|c|c|}
\hline Назва варіанта & Вміст білка, \% & Вміст крохмалю, \% & Вміст фосфору, \% \\
\hline Контроль & $14,2 \pm 0,01$ & $70,1 \pm 0,21$ & $1,15 \pm 0,005$ \\
\hline Діазобактерин & $14,1 \pm 0,12$ & $70,9 \pm 0,26$ & $1,21 \pm 0,009$ \\
\hline Альбобактерин & $14,4 \pm 0,02$ & $73,4 \pm 0,33$ & $1,44 \pm 0,003$ \\
\hline Діазобактерин + Альбобактерин & $14,5 \pm 0,03$ & $72,8 \pm 0,14$ & $1,38 \pm 0,007$ \\
\hline
\end{tabular}




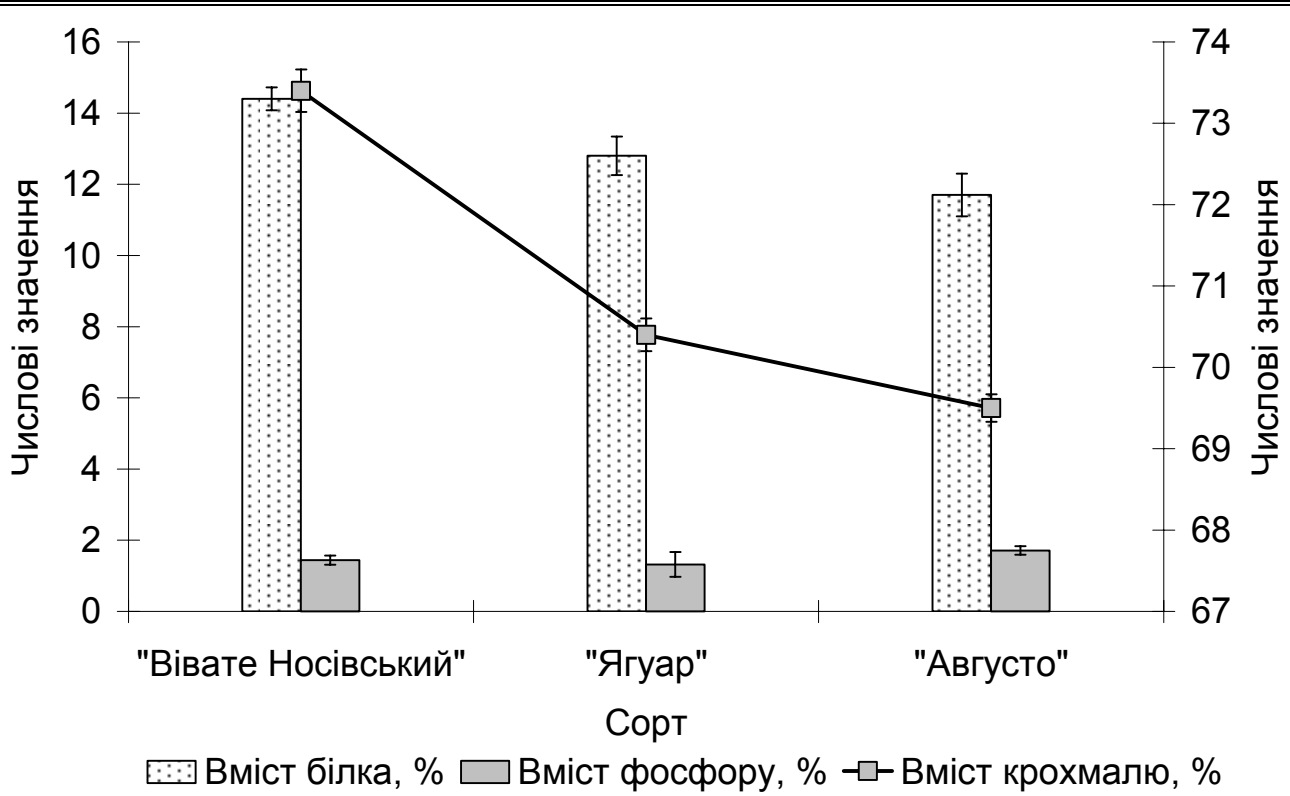

Рис. 1. Реакція сортів тритикале озимого на дію альбобактерину за кількісними параметрами якості зерна, ННДЦ БНАУ, середнє за 2008-2011 рр.

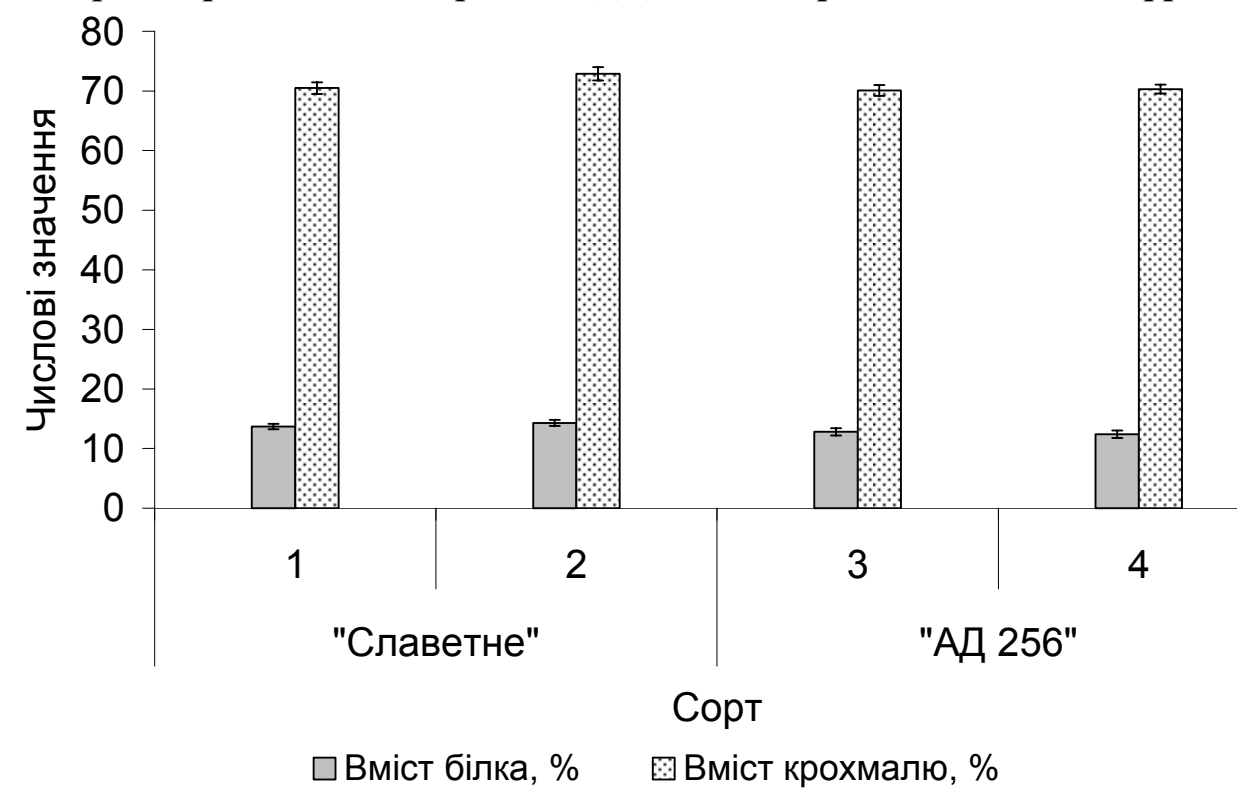

Рис. 2. Реакція тритикале озимого сортів «АД 256» $i$ «Славетне» на дію мікробних препаратів за кількісними параметрами якості зерна, ННДЦ БНАУ, середнє за 2008-2011 рр.: 1 -контроль; 2 - діазобактерин; 3 -альбобактерин; 4-діазобактерин + альбобактерин

Висновки. За результатами досліджень сорти тритикале озимого були диференціювані за чутливістю на дію конкретних біопрепаратів.

Для забезпечення оптимальних цільових параметрів урожаю зерна в умовах центрального Лісостепу на посівах тритикале озимого доцільно проводити передпосівну інокуляцію насіння ефективними штамами мікробних препаратів Azospirillum brasilense - діазобактерину та
Achromobacter album 1122 - альбобактерину, зокрема, на посівах тритикале озимого сорту «Славетне» застосовувати комплекс мікробних препаратів - діазобактерину та альбобактерину; на посівах сортів «Августо», «Ягуар», «Вівате Носівський» застосовувати альбобактерин; «АД 256» - діазобактерин, що істотно $(\mathrm{p} \geq 0,05)$ впливає на збільшення кількісних і якісних параметрів урожайності зерна - на 3-10 \%. 


\section{БІБЛІОГРАФІЯ}

1. Аксенов С. М., Туев Н. А. Принципы построения биологических систем земледелия / Интенсивное земледелие и охрана окружающей среды: Тез. докл. респ. конф. - Волгоград, 1989. - С. 8-11.

2. Біологічний азот: монографія / [В. П. Патика, С. Я. Коць, В. В. Волкогон та ін.]; за ред. В. П. Патики. - К. : Світ, 2003. - 424 с.

3. Доспехов Б. А. Методика полевого опыта / Б. А. Доспехов. - М. : Агропромиздат, 1985. - 351 с. 4. Куперман Ф. М. Морфофизиология растений. Морфофизиологический анализ этапов органогенеза различных жизненных форм покрытосемянных растений: учеб. пособие для биол. спец. ун-тов / Ф. М. Куперман. - 3-е изд., перераб. и доп. - М. : Высш. школа, 1977. - 288 с.

5. Майсурян Н. А. Практикум по растениеводству / Н. А. Майсурян. - Изд. 6-е. - М. : Колос, 1970. $-446 \mathrm{c}$.

6. Методика державного сортовипробування сільськогосподарських культур (зернові, круп'яні та зернобобові культури); Під ред. В. В. Волкодава. - К., 2002. - Вип. 2. - С. 64-66.

7. Мікробні препарати у землеробстві. Теорія i практика: Монографія / [В. В. Волкогон, О. В. Надкернична, Т. М. Ковалевська, Л. М. Токмакова та ін.] ; за ред. В. В. Волкогона. - К. : Аграрна наука, 2006. - $312 \mathrm{c}$.

8. Наумов Г. Ф., Подоба Л. В., Гопщий Т. Н.

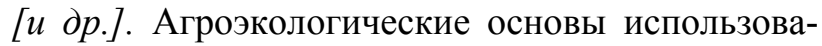
ния биопрепаратов диазотрофных бактерий при выращивании ячменя и амаранта в условиях восточной Лесостепи Украины // Мікробіол. журн. 1997. - 59, № 4. - С. 63-70.

9. Патика В. П., Токмакова Л. М. Пошук мікроорганізмів для поліпшення фосфорного живлення рослин // Бюл. Ін-ту с.-г. мікробіол. - Чернігів, 2000. - № 6. - С. 56-57.

10. Серебряков И. Г. Морфология вегетативных органов высших растений / И. Г. Серебряков. М. : Совецкая наука, 1952. -391 с.

11. Старченков Е. Я. Рациональное сочетание азота минеральных удобрений и биологически связанного симбиотическими системами бобовых // Симбиотрофные азотфиксаторы и их использование в сельском хозяйстве: Тез. докл. респ. конф. - К., 1987. - С. 8-9.

\section{SO ВITIA $\mathcal{M} O$ QR}

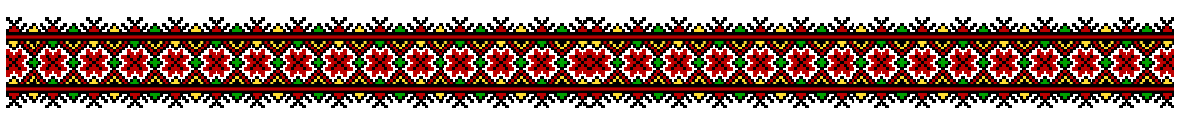

Адміністрація Полтавської державної аграрної академії щиросердно вітає колектив головної державної книгозбірні сільськогосподарської та Аісогосподарської нітератури, третьої за своїми фондами галузевої бібліотеки світу після Національної сільськогосподарської бібліотеки США та Центральної наукової сільськогосподарської бібліотеки Російської академії сільськогосподарських наук, із вагомим державним визнанням - наданням статусу Національної.

Разом із Вами ми пишаємось унікальною науковою установою 3 не тільки понаА мільйонним фондом наукових Ажерел 32-ма мовами із 59-ти країн світу, а й сучасними технічними можливостями Аоведення вікових надбань Ао користувачів.

Зичимо Вам подальших успіхів у виконанні важливої державної справи - наукового інформування українського суспімьства. 